\title{
Potentilla and Fragaria (Rosaceae) reunited
}

\author{
D. J. Mabberley
}

\begin{abstract}
Mabberley, D.J. (Nationaal Herbarium Nederland, University of Leiden, The Netherlands, and Royal Botanic Gardens Sydney, Mrs Macquaries Road, Sydney, NSW 2000, Australia) 2002. Potentilla and Fragaria (Rosaceae) reunited. Telopea 9(4): 793-801. Because morphological, genetic and DNA evidence shows that Fragaria is nested in Potentilla, the former is referred (following Scopoli 1760) to the latter. Remarks on the value of broad generic concepts permitting infrageneric units to be recognized on non-morphological characters are presented. A formal description of the 'intergeneric' hybrid to which the cultivars 'Serenata' and 'Frel' are referred, P. x rosea Mabb., is provided. New combinations and a nomen novum in Potentilla (P. $\mathbf{x}$ ananassa (Rozier) Mabb. [the commercial strawberry], P. chiloensis (L.) Mabb. [one of its parents; new lectotype], P. daltoniana (J. Gay) Mabb., P. iinumae (Mak.) Mabb., P. nilgerrensis (J. Gay) Mabb. [new lectotype] P. nubicola (Hook.f.) Mabb. [new lectotype], P. pentaphylla (Losinsk.) Mabb., P. silvanus Mabb. [Fragaria tibetica] and P. yakusimensis (Masam.) Mabb. [F. nipponica]) are made in a list of species and commercially significant hybrid strawberries generally referred to Fragaria. Some authorities and places of publication of names in current use are also amended.
\end{abstract}

\section{Introduction}

POTENTILLA ... the genus, already extended by the admission of Tormentilla and Comarum, would, perhaps, be still better defined if the Strawberry and Sibbaldia were likewise included. It would then comprise all Rosaceae with a double calyx, distinct 1 -seeded carpels ... and the styles not transformed into long, feathery beaks or awns.

George Bentham, Handbook of the British Flora, p. 192 (1858).

In preparation for corrected reprints of The Plant-book (Mabberley 1997a), it has been necessary to examine the nomenclature of a number of commercially important fruits, notably Citrus (Mabberley 1997b, 1998), Annona spp. (Mabberley 1999a), hybrid grapes (Mabberley 1999c), and apples (Mabberley et al. 2001).

In the last paper, it was shown that, if the genus Malus Mill. (Rosaceae) is maintained, the correct name for orchard apples is M. pumila Mill.: it was pointed out that if a broad view of Pyrus L. is taken, as it was in the early part of the last century, then the name would revert to Linnaeus's, Pyrus malus. It was also pointed out, following Walters (1962), that Fragaria (strawberries, Rosaceae) should be included in Potentilla. Similarly, Amygdalus L., Armeniaca Scop., Cerasus Mill., Laurocerasus Duham., Padus Mill. and Persica Mill. are back in Prunus L. (Rosaceae; Bortiri et al. 2001); Lycopersicon Mill. and Cyphomandra Sendtner are now in Solanum (Solanaceae; Spooner et al. 1993, Bohs 1995); Lychnis L. falls into Silene L. s.l. (Caryophyllaceae; Mabberley 1999b; unless that be shattered and unfamiliar segregates be recognized [Lidén et al. 2000]); Acidanthera Hochst., Anomalesia N.E. Br. and Homoglossum Salisb. (Petamenes Salisb. ex J.W. Loudon) are in Gladiolus L. (Iridaceae; Goldblatt \& Manning 2000: 125); Cheiranthus L. is in Erysimum L. (Cruciferae) while Diplycosia Bl., besides Pernettya Gaud., is in Gaultheria Kalm ex L. (Powell \& Kron 2001), Ledum L. and probably other genera are in Rhododendron L., and Philippia Klotzsch and many other splits (Goldblatt 
\& Manning 2000: 423) are included in Erica L. (Ericaceae); Heliocereus (A. Berger) Britton and Rose and Nopalxochia Britton and Rose are in Disocactus Lindl., while Lobivia Britton and Rose is in Echinopsis Zucc. (Cactaceae); Stephanotis Thouars is in Marsdenia R. Br. (Apocynaceae s.l.) - see Mabberley (1997) for details; Fortunella Swingle and Poncirus Raf. are back in Citrus L. (Rutaceae; Mabberley 1998, Mabberley 2002); Mahonia Nutt. is back in Berberis L. (Berberidaceae; Whittemore 1997); Sansevieria Thunb. falls into Dracaena L. (Convallariaceae; Bos 1998), and Chysalidocarpus H. Wendl. into Dypsis Mart. (Palmae; Dransfield \& Beentje 1995: 123). With such changes, it is now possible to recognize monophyletic rather than paraphyletic genera in all of these groups: such 'intergeneric' hybrids as $x$ Citrofortunella J. Ingram and H. Moore and x Citroncirus J. Ingram and H. Moore (Rutaceae), x Gaulnettya Marchant (Ericaceae), x Heliochia G. Rowley (Cactaceae) and $\mathrm{x}$ Mahoberberis C. Schneider (Berberidaceae) consequently disappear.

There can be no doubt that further molecular work in remodelling the relationships of plant taxa, will, in many cases, restore the broad view of genera: it may well be that horticulturists' reticence in retaining this broad view, in say, Amaryllis L. (including Hippeastrum Herb., Amaryllidaceae), Hibiscus L. (including Abelmoschus Medik., Malvaviscus Fabr., Malvaceae) and Veronica L. (including Hebe Juss., Scrophulariaceae/Veronicaceae) will be vindicated.

\section{The Fragaria problem}

For a historical account of the fate of genera ascribed to the Potentilla group, see Erikkson et al. (1998), who review the differing elaboration of the torus into a fleshy receptacle bearing achenes, typical of strawberries, but a condition probably arrived at more than once in the group. The important genera to be considered in this study include several that Linnaeus recognized as distinct, but are now generally incorporated in Potentilla L., a genus of some 500 species (Mabberley 1997a: 581). Within Fragaria, a genus of perhaps 12-15 species and the only one which is widely kept distinct now, Linnaeus described F. sterilis L., named for its not having a fleshy receptacle and thus being inedible. Even for him then, the fleshy nature of the 'strawberry fruit' was less important than other features. Smith (1800: 547) pointed out that F. sterilis is intermediate between the Linnaean genera Fragaria and Comarum and, shortly afterwards, Persoon (1806-7) transferred it to Potentilla, giving it the illegitimate name P. fragariastrum Ehrh. ex Pers., since corrected to P. sterilis (L.) Garcke1. It lacks the typical 'strawberry', although its overall facies is superficially very similar to F. vesca L., such that the 'generic' distinction has confused professional and amateur alike ever since.

Of the genera Linnaeus kept distinct from Potentilla, Scopoli (1760: 572) subsumed Tormentilla L., Comarum and Fragaria in Potentilla. The bulk of the remaining genus, Sibbaldia L., which is concentrated in the Himalaya, was later included in Potentilla by Joseph Hooker (thereby following Bentham's suggestion - see above) in his Flora of British India $(2: 345,1878)$. The collecting of certain wild plants believed to be hybrids between Sibbaldia procumbens L. (i.e. P. sibbaldii Hall.f.) and Fragaria virginiana Mill. (Staudt 1999: 100) supports the inclusion of Sibbaldia in Potentilla.

\footnotetext{
1 These Potentilla names are incorrectly cited in Index Kewensis, IPNI etc. and were published as follows: Potentilla fragariastrum Ehrh. ex Pers., Syn. 2: 56 (1806), nom. illeg., nom. superfl. pro F. sterilis L., i.e. Potentilla sterilis (L.) Garcke, Fl. Halle 2: 200 (1856).
} 
Most striking perhaps in the current context, though long since 'sunk', is Comarum, which has a somewhat swollen receptacle intermediate between that of a typical Fragaria and Potentilla: the type, now P. palustris (L.) Scop., is one of the parents of the recently selected cultivars 'Frel' (US Patent in 1989) and 'Serenata' (US Patent in 1991). Ellis (1962) was the first to report crosses made between the hexaploid Potentilla palustris, of Eurasia and North America, and the octoploid garden strawberry, Fragaria $x$ ananassa Duch. ex Rozier (as F. grandiflora), a cross between two American species. He recorded that the hybrids were heptaploid and had pink petals intermediate between the purple ones of $P$. palustris and the white ones of the strawberry.

Since that time, back crosses with strawberries have been made and released into commerce under the names 'Frel' and 'Serenata' (which is a further back cross, between 'Frel' Pink Panda ${ }^{\mathrm{TM}}$ and a strawberry). Because of the repeated backcrossing with strawberries in its ancestry, 'Frel' is regarded as a strawberry for patent purposes and is referred to as a Fragaria cultivar (Leslie 1995). From a botanical standpoint it is one of the Potentilla-Fragaria hybrid complex and it should be afforded an intergeneric name if the genera Potentilla and Fragaria are to be kept separate (Mabberley 1997: 287).

Potentilla has sometimes been shorn of some subgroupings, notably the shrubby Dasiphora Raf. ('Pentaphylloides Duham.', Duhamel's true Pentaphylloides being a synonym of Potentilla s.s. (Erikkson et al. 1998)), but molecular work has shown that Potentilla as presently understood is paraphyletic if Dasiphora, Fragaria, and those Fragaria species sometimes referred to Duchesnea Sm., are excluded from it. Now Duchesnea, species of which have a swollen torus but insipid 'fruits', has been formally moved to Potentilla (Kalkman 1968, following Wolf [1908]), and Dasiphora is almost never used. Hybrid seedlings have been raised between the type species of Potentilla, $P$. reptans L., and the commercial strawberry (Ellis 1962).

As conclusions based on morphological characters have been resoundingly confirmed by both molecular and breeding studies, either the rest of Fragaria is brought in or the genus Potentilla must be fragmented (Erikkson et al. 1998) into narrowly defined genera with unfamiliar names. At this stage monophyletic units in Potentilla s. $l$. are not clear and I therefore concur with Craven (2001), when dealing with large genera such as this. In discussing Syzygium L. (Myrtaceae), he writes, 'It is undesirable to optimistically propose new genera based on flimsy differences and hypocrisy to continue using definite invalid ones'.

Continuing to use Potentilla in the broad sense will provide continuity of names for almost all of the species so far described, though other genera may also be drawn in (Erikkson et al. 1998). Should infrageneric groupings be recognized later, they can be given infrageneric names (cf. Davis \& Heywood 1963: 106, Mabberley 1997: xii). In so doing, such clades can, if necessary, be defined by molecular parameters, thereby obviating the need for botanists having to strive to find ever more obscure 'morphological features', which are ever more unusable for the layman trying to identify 'taxa' given names associated with ranks. There is, after all, no theoretical reason to suppose that all clades will be recognisable by eye, for evolution may act on chemical constitution, disease resistance etc., which can be more important as 'characters' to ecological forces or creatures such as fungi acting on plants.

\section{Nomenclature}

Although the genera Fragaria and Potentilla have been combined since at least the time of Scopoli (1760), the fact that the receptacle of strawberries is edible, while that of Potentilla s.s. is not - a prime example of 'folk taxonomy' (Walters 1962), has encouraged their being kept separate right up until today. Despite the fact that, 
following Bentham, both Ellis (1962) and Kalkman (1968) argued the case for amalgamation, they did not take the step they advocated (see also van der Meijden 1996: 235), the sole argument for not so doing being the nomenclatural one. However, long ago, Prantl (1884), and Krause (1904: 102) followed Scopoli (1771: 363, who was the first to make a new combination in Potentilla for a Fragaria), and transferred other Fragaria names to Potentilla, so that there are names in Potentilla available for use for some of the strawberries (see below), as well as most species of Sibbaldia and Duchesnea.

The reason for modern authors' reticence (see e.g. Erikkson et al. 1998) has in large part been because it was thought that Potentilla had been first included in Fragaria (Crantz 1763: 9 ; 1766: 176), so that it was believed necessary under the present Code to transfer several hundred other Potentilla names to Fragaria. This was clearly nonsensical and not in the interests of nomenclatural stability, but a successful proposal for the conservation of Potentilla over Fragaria would have removed this threat.

Fortunately, study of the work of Scopoli shows that it is unnecessary to do even that, because Scopoli (1760: 572) wrote under his entry for the genus Potentilla, 'Non opus est itaque ex Potentilla, Tormentilla, Comaro and Fragaria, totidem diversa genera constituere, contra Naturam'. Amongst his listing, which does not use Linnaeus's shorthand binomial system but quotes verbatim Linnaeus's phrase-names from Species Plantarum, he includes what is now called Fragaria vesca L., the type of Fragaria, and Potentilla reptans L., the type of Potentilla.

The consequence of this is that all that is now required is the transfer of the few remaining strawberry names, including the hybrid cultivars 'Frel' and 'Serenata', to Potentilla. Although the name-changes, like all name-changes, may be regretted, it is unlikely that the industry, which, unlike in its marketing of ornamentals, rarely uses the Latin names for strawberries in any case, will object strongly. Naturally those resisting the flow of rising scientific opinion (see Sanders \& Judd 2000) by wishing to maintain Fragaria in its current circumscription as a separate genus, thereby recognising a paraphyletic Potentilla, can continue to use the names published in Fragaria. Even so, for them the names of the hybrids from which 'Frel' and 'Serenata' were bred are still a problem from a botanical standpoint without an 'intergeneric' name. Moreover, even if Fragaria is maintained, there are some clarifications of typifications needed.

The species and hybrid names needed for a new edition of The Plant-book (Mabberley 1997) and those other names widely used in modern Floras and the trade or plantbreeding (see Staudt 1962, 1989, 1999, Staudt \& Dickoré 2001) for distribution etc. of species for which new names are not proposed here and/or are not grown in Australia) are therefore as follows (an asterisk indicates amendments or additions to Index Kewensis, IPNI etc.):

1. *Fragaria x ananassa [Duch. ex] Rozier, Cours Comp. Agric. 5: 52, t. 5, fig. 1 (1785), i.e. P. virginiana (Mill.) E.H.L. Krause $\mathrm{x}$ P. chiloensis (L.) Mabb., = Potentilla $\mathbf{x}$ ananassa (Rozier) Mabb., comb. nov.

Type: Cultivated in France, A.N. Duchesne '9' [Herb. Linn. 654.19], 'le fraisier-ananas. Fragaria ananassa' scrips. Duchesne (LINN, fiche), lecto selected by Staudt (1962: 884).

As pointed out by Navarro and Muñoz Garmendia (1998), Duchesne's binomial was first validated by Rozier. Rozier's herbarium was at the Lyon Palais des Arts, France, but, after investigation, Professor Ph. Morat (P) wrote (pers. comm.), 'Depuis [1900] les archives ont été distribuées en deux parties: l'une a été dirigée vers la Bibliothèque municipale, l'autre vers la Bibliothèque de l'Académie des Sciences, Belles Lettres et Arts de cette même ville. Dans les deux endroits les recherches ont été infructueuses.' Until the herbarium is found and examined, the published plate could perhaps serve 
as lectotype, but, as Rozier (l.c.) wrote, 'Nous suivrons l'order qu'il [Duchesne] a établi', there is perhaps sufficient link to Duchesne's work and collection, thereby supporting Staudt's typification pro tem.

Notes: This is the octoploid garden strawberry (P. chiloensis $\times$ P. virginiana) as cultivated in Australia and all over the temperate world for the fruit trade. Some 2.5 million tonnes were traded in 1999 (Hancock 1999: 1). The most important cultivars grown in Australia are those bred in California, and, of those, 'Camarosa' is the world's most widely planted (Hancock 1999: 13). Potentilla $\mathrm{x}$ ananassa is one of the parents of $P . \times$ rosea, the other being $P$. palustris.

2. Fragaria chiloensis (L.) Mill., Gard. Dict. Edn 8, Fragaria no. 4 (1768) = Potentilla chiloensis (L.) Mabb., comb. nov.

Basionym: Fragaria vesca L. var. chiloensis L., Sp. Pl.: 495 (1753).

Type [icon, reproduced here]: Dillenius, Hort. Elth. t. 120, f. 146 (1732), lecto, selected here.

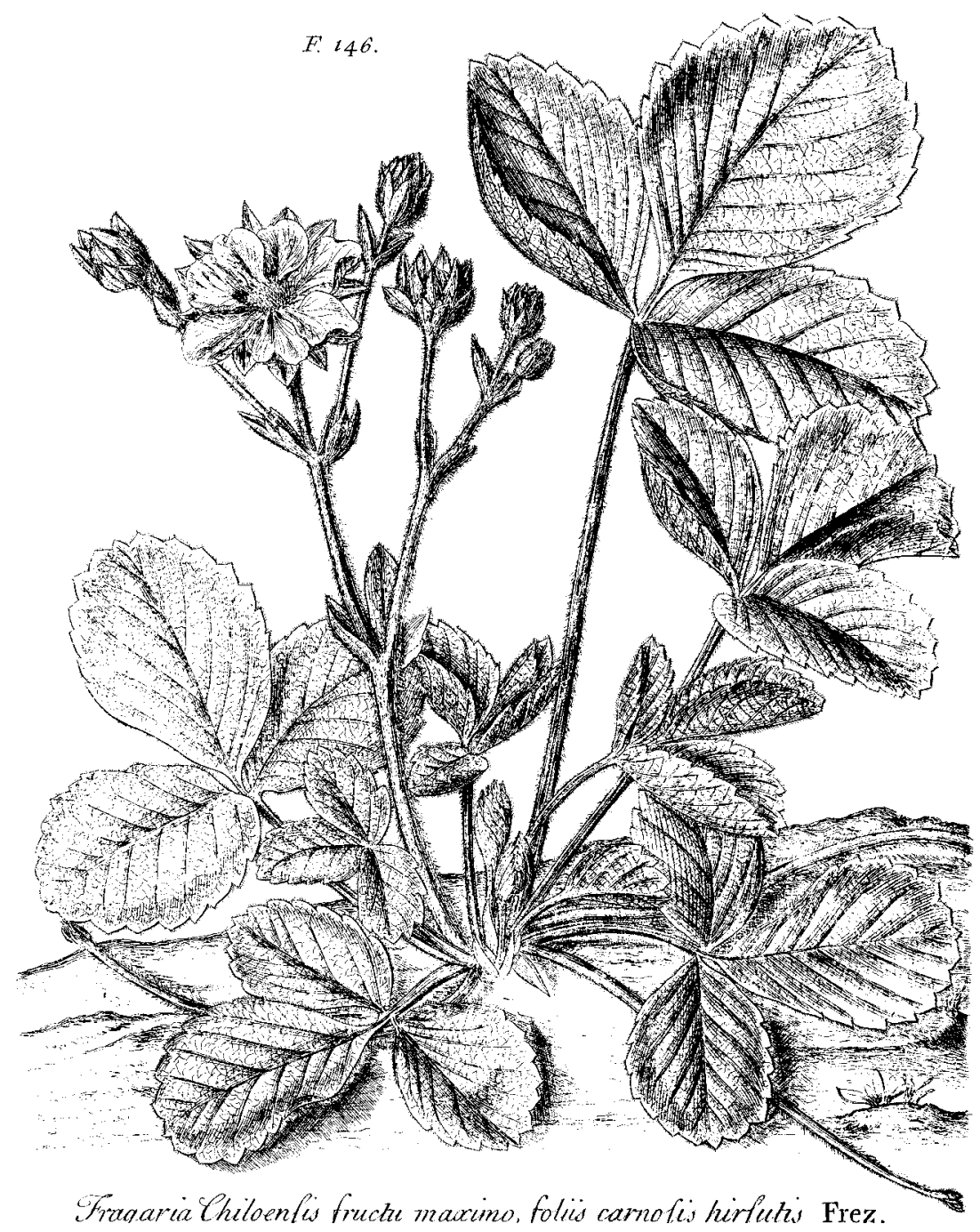


There is no original herbarium material in the Linnaean herbaria, the specimen LINN 654.21 selected by Staudt $(1962$ : 881; 1999: 100) being a post-1753 addition to Linnaeus's own herbarium (Charlie Jarvis, pers. comm.), so the only element Linnaeus cited, Dillenius's plate, is here chosen as lectotype. Typotype material (most probably examined by Linnaeus during his visit to Oxford in 1736 - see Clokie 1964: 201) is in Herb. Dillenius (OXF [photo seen]); a sheet (1053/2) in Herb. Sherard (OXF) is possibly a duplicate (Serena Marner, pers. comm.).

Notes: west coasts of North and South America; one of the octoploid parents of $P . \mathrm{x}$ ananassa. Cultivated in Australia.

3. Fragaria daltoniana J. Gay in Ann. Sci. Nat. IV, 8: 204 (1857) = Potentilla daltoniana (J. Gay) Mabb., comb. nov.

Type: Sikkim, '10-12000 ped.', J. D. Hooker s.n. in herb. J.D. Hooker and T. Thomson $(\mathrm{K}$, holo; $\mathrm{K}$, iso; OXF, iso [photocopy seen]; $\mathrm{P}$, iso).

Notes: Himalaya, N Burma. Diploid.

4. Fragaria 'Frel' and 'Serenata' = cultivars of Potentilla x rosea Mabb., hybr. nova (Potentilla palustris (L.) Scop. x P. x ananassa (Rozier) Mabb.)

Hybrida hortensis, heptaploidea, e P. palustre (L.) Scop. et $P$. $x$ ananassa (Rozier) Mabb. exorta, inter parentes media, insigniter corolla rosea.

Type [icon]: Proc. Linn. Soc. London 173, t. 2, excl. fig. 5 (1962).

Notes: Jack R. Ellis first synthesized such heptaploid hybrids at University College London and, using colchicine, produced 14 -ploid plants $(2 \mathrm{n}=98)$ with enhanced fertility (Ellis 1962). Since that time he has raised back-crosses with $P$. x ananassa to give the named cultivars (see above) with much lower chromosome numbers.

The named cultivars are therefore $P$. x rosea Mabb. 'Frel' and its offspring 'Serenata' $(2 n=58)$. No material of the original cross was preserved (Jack Ellis, pers. comm.), so the photographs of it are here designated the type.

'Frel' (as Pink Panda ${ }^{\mathrm{TM}}$ ) is grown in Australia.

5. Fragaria indica Jacks. (Duchesnea indica (Jacks.) Focke) = Potentilla indica (Jacks.) T. Wolf

6. Fragaria iinumae Mak. in Bot. Mag. Tokyo 21: 156 (1907) = Potentilla iinumae (Mak.) Mabb., comb. nov. (syn. P. daisenensis Honda)

Type: Makino cites only the illustration (t. 28) in Y. Iinuma's Sintei Sōmoku-Dzusetsu 9 (1874), but the description is clearly drawn up from other material not cited (?TI, n.v.). At UC is a sheet labelled 'Makino Herbarium 367 89', Japan, Yamagata Pref., Akumigun, Mt. Chokai, 1928, T. Makino s.n., for example.

Notes: Japan, Sakhalin. Diploid.

7. *Fragaria moschata Weston, Bot. Univ. 2: 327 (1771) = Potentilla moschata (Weston) Prantl

Notes: Europe. Hexaploid. Cultivated in Australia.

8. Fragaria moupinensis (Franchet) Cardot = Potentilla moupinensis Franchet

9. Fragaria nilgerrensis [Schldl. ex] J. Gay in Ann. Sci. Nat. IV, 8: 206 (1857) = Potentilla nilgerrensis ( $J$. Gay) Mabb., comb. nov.

Type: India, Nilgiri Mts, J.D. Hooker and T. Thomson s.n. (K, lecto, selected here; OXF, isolecto [photocopy seen]; $\mathrm{P}$, isolecto). 
Staudt (Bot. Jahrb. 121: 299 [1999]) has selected a Metz sheet from Robert Wight's herbarium (now at K) as 'lectotype', with a P sheet as 'isolectotype' ('isolecto' - L). Although Gay took the name from Schlechtendal's unpublished one on a Metz sheet (F. Metz s.n. in Hohenacker, Pl. Ind. Or. Exsicc. n. 1578), his description is based on the Hooker and Thomson sheet.

Notes: Nilgiris (SW India), Khasia Mts (NE India), Sikkim to China. Diploid.

10. Fragaria nipponica Mak. in Bot. Mag. Tokyo 25: '(229)' (1911, japonice) and 26: 282 (1912, anglice), non Potentilla niponica T. Wolf [sic], = Potentilla yakusimensis (Masam.) Mabb., comb. nov.

Basionym: Fragaria yakusimensis Masam. in J. Soc. Trop. Agric. Taiwan 3: 115 (1931).

Type: Japan, Yaku Is., Ōsumi Province, June 1928, G. Masamune s.n.. (TAI, not found, so perhaps transferred to a Japanese herbarium (Chen-Meng Kuo (TAI), pers. comm.), TI? - not found, T. Kajita (TI), pers. comm.).

Notes: Japan, Korea. Diploid.

11. Fragaria nubicola (Hook.f.) [Lindl. ex] Lacaita = Potentilla nubicola (Hook.f.) Mabb., comb. nov.

Basionym: Fragaria vesca L. var. nubicola Hook.f., Fl. Brit. India 2: 344 (1878).

Type: Tibet (Xixang), Gosainthan [28 22'N, 8550'E], 'Potentilla sp.', Anon [? Bharat Singh] in East India Company 1238/1 (K, lecto selected here; K-W, isolecto).

Notes: Bokhara to Sikkim. Diploid.

12. Fragaria pentaphylla Losinsk. in Izv. Glavn. Bot. Sada SSSR 25: 69 and t. 4 (1926), = Potentilla pentaphylla (Losinsk.) Mabb., comb. nov.

Type: China, Kansu, Li-dscha-pu, 20 June 1885, G.N. Potanin s.n. (LE, lecto [selected by Stepanova in Staudt \& Dickoré 2001: 344], n.v.; US, isolecto, photocopy seen). Note that Potentilla pentaphylla Richter ex Pohl (1814, i.e. P. recta L.) was a name only ever published in synonymy.

Notes: southwest China. Diploid.

13. Fragaria tibetica Staudt and Dickoré in Bot. Jahrb. Syst. 123: 349 (2001), non Potentilla thibetica Cardot (1916), = Potentilla silvanus Mabb., nom. nov.

Type: [Cult.,] Germany, Merzhausen near Freiburg [ex Tibet (Xixang), Everest (Qomolangma) E, Kama Chu, W of Sakyetang, 10 Oct 1989, W.B. Dickoré s.n.], s.d., W.B. Dickoré s.n. (B, holo, digital image seen). The new specific name commemorates the Nestor of strawberry systematics, Prof. dr. Günther Staudt, monographer of Fragaria. According to Hanks and Hodges (1988: 510), the surname Staudt is a variant of Staude, a name for someone living by a patch of uncleared dense undergrowth, a name cognate with the Old High German word stüda, a thicket or wilderness. The Roman God associated with such uncultivated land is Silvanus (Rose 1970), hence the epithet, which is a substantive; coincidentally, and happily, the habitat for this strawberry is said to include upper montane scrub (Staudt \& Dickoré 2001), beyond areas of cultivation.

Notes: southwest China. Tetraploid, allegedly derived from P. pentaphylla (Staudt \& Dickoré 2001). 
14. Fragaria vesca L. = Potentilla vesca (L.) Scop.

Notes: Cultivars of this are the 'alpine' strawberries of patisserie. Diploid. Cultivated in Australia (material apparently brought with the First Fleet, 1788), this North Temperate species is naturalized in New Zealand.

15. Fragaria virginiana Mill. $={ }^{*}$ Potentilla virginiana (Mill.) E.H.L. Krause, Sturm's Fl. Deutschland 8: 111 (1904) and Zweites Register [8]: 1 (1909?).

Note that although the meaning in the main text is clear, the basionym is cited only in the second index to the whole work.

Notes: This is an octoploid parent of $P . \mathrm{x}$ ananassa.

16. *Fragaria viridis Weston, Bot. Univ. 2: 327 (1771) = Potentilla viridis (Weston) Prantl (April 1884; nec *Potentilla viridis (Koch) Zimmeter in Jahres-Ber. Staats-OberRealschule Steyer 14: 6 [Aug.-Sept. 1884], i.e. P. anserina L., non *Potentilla viridis (Neilr.) Fritsch, Excursionsfl. Oesterreich: 295 [1897], i.e. P. pusilla Host)

\section{Acknowledgments}

I am grateful to Walter Lack (B, who also arranged for the transmission of a digital image of material in Berlin), Henry Noltie (E), Ben Pollard (K) and Anne Sing (FHO) for tracking down literature not available to me in Australia, to Susyn Andrews (K), Jack Ellis, Ken Muir and Adrian Whiteley (WSY) for information on P. x rosea cultivars, to Véronique Durand $(\mathrm{P})$ for xeroxes of material in the Paris herbarium, Charlie Jarvis (BM) for advice on Linnaean typification, Tadashi Kajita (TI) for information on types in Tokyo, Chen-Meng Kuo (TAI) for advice on specimens in Taipei, Serena Marner (OXF) for information on Dillenius's herbarium, Dan Nicolson (US) for a xerox of material in Washington, Roy Vickery (BM) for information on the Lacaita herbarium, and Tim Waters (FHO) for information on material at Kew.

\section{References}

Bohs, L. (1995) Transfer of Cyphomandra (Solanaceae) and its species to Solanum. Taxon 44: 583-587.

Borteri, E., Oh, S.-H., Jiang, J., Baggett, S., Granger, A., Weeks, C., Buckingham, M., Potter, D and Parfitt, D.E. (2001) Phylogeny and systematics of Prunus (Rosaceae) as determined by sequence analysis of ITS and the chloroplast trnL-trnF spacer DNA. Syst. Bot. 26: 797-807.

Bos, J.J. (1998) Dracaenaceae. Pp. 238-241 in K. Kubitzki (ed.), The Families and Genera of Vascular Plants 3. (Springer: Berlin).

Clokie, H.N. (1964) An account of the herbaria of the Department of Botany in the University of Oxford. (Oxford University Press: Oxford).

Crantz. H.J.N. (1763) Stirpium Austriarum Fasciculus II. (Krauss: Vienna).

Crantz, H.J.N. (1766) Institutiones rei herbariae juxta nutum naturae digestae ex habitu, vol. 2. (Krauss: Vienna).

Craven, L.A. (2001) Unravelling knots or plaiting rope: What are the major taxonomic strands in Syzygium sens. lat. (Myrtaceae) and what should be done with them? Pp. 75-85 in L.G. Saw et al. (eds), Taxonomy: the Cornerstone of Biodiversity (Proceedings of the Fourth International Flora Malesiana Symposium 1998). (Forest Research Institute Malaysia Kepong: Kuala Lumpur).

Davis, P.H. and Heywood, V.H. (1963) Principles of Angiosperm Taxonomy. (Oliver and Boyd: Edinburgh \& London).

Dransfield, J. and Beentje, H.J. (1995) The Palms of Madagascar. (Royal Botanic Gardens Kew: Richmond).

Ellis, J.R. (1962) Fragaria-Potentilla intergeneric hybridization and evolution in Fragaria. Proc. Linn. Soc. London 173: 99-106. 
Erikkson, T., Donoghue, M.J. and Hibbs, M.S. (1998) Phylogenetic analysis of Potentilla using DNA sequences of nuclear ribosomal internal transcribed spacers (ITS), and implications for the classification of Rosoideae (Rosaceae). Pl. Syst. Evol. 211: 155-179.

Goldblatt, P. and Manning, J. (2000) Cape Plants. A conspectus of the Cape Flora of South Africa. Strelitzia 9.

Hancock, J.F. (1999) Strawberries. (CAB International: Wallingford, UK).

Hanks, P. and Hodges, F. (1988) A Dictionary of Surnames. (Oxford University Press: Oxford).

Kalkman, C. (1968) Potentilla, Duchesnea, and Fragaria in Malesia. Blumea 16: 325-354.

Krause, E.H.L. (1904) J. Sturm's Flora von Deutschland, 8 band: Rosen, Rosiflorae. (Lutz: Stuttgart).

Leslie, A.C. (1995) Fragaria. Pp. 397-98 in J. Cullen et al. (eds), The European Garden Flora 4. (Cambridge University Press: Cambridge).

Lidén, M., Popp, M. and Oxelman, B. (2000) A revised generic classification of the tribe Sileneae (Caryophyllaceae). Nord. J. Bot. 20: 513-18.

Mabberley, D.J. (1997a) The Plant-book, edn 2 [corrected reprints 1999, 2000]. (Cambridge University Press: Cambridge).

Mabberley, D.J. (1997b) A classification for edible Citrus. Telopea 7: 167-172.

Mabberley, D.J. (1998) Australian Citreae (Rutaceae) with notes on other Aurantioideae (Rutaceae). Telopea 7: 333-344.

Mabberley, D.J. (1999a ['1998']) Taxonomic appendix. Pp. 143-44 in G.K. Tam, Paradisus - the Hawaiian Plant Watercolors of Geraldine King Tam. (Honolulu Academy of Arts: Honolulu).

Mabberley, D.J. (1999b) Silene banksia (Caryophyllaceae), an ancient garden plant. Telopea 8: 249-256.

Mabberley, D.J. (1999c) Vitis x alexanderi Prince ex Jacques (Vitaceae), the first 'American Hybrid' grapes. Telopea 8: 377-79.

Mabberley, D.J. (2002, in press) Limau hantu and limau purut: the story of lime-leaves (Citrus hystrix DC., Rutaceae)? Gard. Bull. Sing. 54.

Mabberley, D.J., Jarvis, C.E. and Juniper, B.E. (2001) The name of the apple. Telopea 9: 421-430.

Meijden, R. van der (1996) Heukels' Flora von Nederland, 22 ${ }^{\text {nd }}$ edn. (Wolters-Noordhoff: Groningen).

Navarro, C. and Muñoz Garmendia, F. (1998) Fragaria. Pp. 88-94 in S. Castrojevo (ed.), Flora Iberica 6. (Real Jardín Botánico, CSK: Madrid).

Persoon, C.H. (1806-7) Synopsis Plantarum. (Cramerum: Paris; Cottam: Tubingen).

Powell, E.A. and Kron, K.A. (2001) An analysis of the phylogenetic relationships in the wintergreen group (Diplycosia, Gaultheria, Pernettya, Tepuia; Ericaceae). Syst. Bot. 26: 808-817.

Prantl, K. (1884) Exkursionsflora für das Königreich Bayern. (Ulmer: Stuttgart).

Rose, H. J. (1970) Silvanus. P. 990 in N.G.L. Hammond and H.H. Scullard, The Oxford Classical Dictionary, edn 2. (Oxford University Press: Oxford).

Sanders, R.W. and Judd, W.S. (2000) Incorporating phylogenetic results into floristic treatments. Sida, Bot. Misc. 18: 97-112.

Scopoli, J.A. (1760) Flora Carniolica. (Trattner: Vienna).

Scopoli, J.A. (1771) Flora Carniolica edn 2, vol. 1. (Krauss: Vienna).

Smith, J.E. (1800) Flora Britannica, vol. 2. (Davis: London).

Spooner, D.M., Anderson, G.J. and Jansen, R.K. (1993) Chloroplast DNA evidence for the interrelationships of tomatoes, potatoes and pepinos (Solanaceae). Amer. J. Bot. 80: 676-688.

Staudt, G. (1962) Taxonomic studies in the genus Fragaria. Typification of Fragaria species known at the time of Linnaeus. Can. J. Bot. 40: 869-886

Staudt, G. (1989) The species of Fragaria, their taxonomy and geographical distribution. Acta Hortic. 265: 23-33.

Staudt, G. (1999) Systematics and geographic distribution of the American strawberry species. Taxonomic studies in the genus Fragaria. Univ. Calif. Publ. Bot. 81.

Staudt, G. and Dickoré, W.B. (2001) Notes on Asiatic Fragaria species: Fragaria pentaphylla Losinsk. and Fragaria tibetica spec. nov. Bot. Jahrb. Syst. 123: 341-354.

Walters, S.M. (1962) The shaping of angiosperm taxonomy. New Phytol. 60: 74-84.

Whittemore, A.T. (1997) Berberis. Pp. 276-286 in Flora of North America Editorial Committee, Flora of North America 3. (Oxford University Press: New York).

Wolf, T. (1908) Monographie der Gattung Potentilla. Bibl. Bot. 71. 
